\title{
Stratigraphy and Foraminiferal Biostratigraphy of Sentolo Formation in Sedayu Area: Local Unconformity Identification in Early Pliocene
}

\author{
Akmaluddin, Muhammad Virgiawan Agustin, and Ma'ruf Kurniawan Adi \\ Department of Geological Engineering, Faculty of Engineering, Gadjah Mada University, Yogyakarta, Indonesia
}

\begin{abstract}
The study area is located in Sedayu District, Bantul Regency, Special Region of Yogyakarta Province which belongs to the Sentolo Formation. This area is an interesting place to study because there are erosional boundaries that indicate an unconformity in the Sentolo Formation. In this study, stratigraphic measurements and sampling were carried out in the field, then the samples were prepared and analyzed for the content of planktic and benthic foraminifera fossil. The results of the analysis are the determination of biozonation, paleobathimetry, and identification of sedimentation rates and unconformity. From the data analysis, ware known that the Sentolo Formation in Sedayu area can be divided into three lithofacies, namely thickening upward calcareous sandstone calcareous siltstone facies, channel calcareous sandstone - calcareous siltstone facies and thinning upward limestone facies. Based on the biostratigraphy analysis, can be divided into four biozonations, namely the PL1A, PL1B, PL1C, and PL2 zones which are included in the Early Pliocene age. There is an unconformity in the facies boundary of the channel calcareous sandstone - calcareous siltstone facies with thinning upward limestone facies, identified by the presence of an erosional boundary at that interval and also supported by sudden changes in paleobatimetry from Upper Bathyal to Middle Neritic. The sedimentation rate identified in this area has a value of $15.5 \mathrm{~m} /$ Ma which identified in the lower facies. The extrapolation results of age and sedimentation rates concluded that the unconformity occurred at 4.46-4.20 Ma, and eroded $4.03 \mathrm{~m}$ thick of sedimentary rocks.
\end{abstract}

Keywords: Biostratigraphy $\cdot$ Local unconformity identification $\cdot$ Early Pliocene $\cdot$ Sentolo Formation.

\section{INTRODUCTION}

The Sentolo Formation is one of the Kulon Progo Mountains Zone which is generally consist of marl and limestone. Stratigraphically, the Sentolo Formation has a inter-fingering relationship with the Jonggrangan Formation. According to Rahardjo et al. (1995), the Sentolo Formation was formed in Late Miocene until Early Pliocene, while Surono et al. (1986) state that the age of Sentolo Formation is Middle Miocene to Late Miocene. The existence of differences of opinion about the age of this Forma-

\footnotetext{
${ }^{*}$ Corresponding author: AKMALUdDIN, Department of Geological Engineering, Gadjah Mada University. Jl. Grafika 2 Yogyakarta, Indonesia. E-mail: akmaluddin@ugm.ac.id
}

tion makes the Sentolo Formation quite interesting for biostratigraphic research.

In Sedayu area, Bantul Regency, Yogyakarta, there are rock outcrops of the Sentolo Formation which form a continuous stratigraphic succession. The outcrop is composed of carbonate sandstones and marl at the bottom and limestone at the top, which is restricted by an erosional boundary. The encounter of erosional boundaries is interesting, because it indicates an unconformity in the Sentolo Formation that has never been found in previous studies. However, it needs to be reviewed whether the erosion boundary is an unconformity or only a deposition structure due to scour. Therefore, it is interesting to do a detailed biostratigraphic study on the fossil content in the out- 
crop to determine whether there is a unconformity boundary in between sandstone-marl with limestone units.

This research was conducted with the intention of identifying the content of fossils of planktic and benthic foraminifera that found on the tracks that located in the study area. The research objective was to determine the foraminifera biostratigraphy zone and identification of the depositional environment of the Sentolo Formation in the Sedayu area to prove indications of unconformity in the intra-Sentolo Formation.

\section{Geolocal Setting}

The research area in general is included in the Kulon Progo Mountains Zone which has a morphology in the form of a oblong dome with a height to $1,022 \mathrm{~m}$ which is formed due to the undulation process (Van Bemmelen, 1949). According to Rahardjo et al. (1995), the research area included in the Sentolo Formation, which is deposited on top of the Old Andesite Formation and inter-fingering with the Jonggrangan Formation (Figure 1). The rocks that compose the Sentolo Formation from the bottom to the top consist of agglomerates and marl, interbedded limestone and thin marl will be found on the upper part. The thickness of the Sentolo Formation ranges from 500-700 meters, formed in shallow marine environment and has a range of ages N7-N21 (Middle Miocene-Pliocene).

\section{Methods}

The method used in this study starts from field data collection such as stratigraphic measurement and rock sampling. In field data collection requires equipment including jacob sticks, geological hammers, rock sample bags, $\mathrm{HCl}$, cameras, measured section columns, and field notebooks. Retrieval of stratigraphic measurement data using the Jacob Stick method, produces stratigraphic measurement data of \pm 20 meters thick, which is recorded into the stratigraphic measurement column with a scale of 1:100 to obtain information about rock characteristics including color, texture, sedimentary structure, rock composition, strike/dip of layer, and thickness of the rock. Rock sampling is carried out systematically at intervals of every 1 meter. Rock samples were taken on rocks that have fine grain size and calcareous using a geological hammer and stored on the sample bag. The carbonate content of rocks are shown through the release of foam when the dropping test of $0.1 \mathrm{M} \mathrm{HCl}$ solution is carried out. Systematic sampling is carried out by looking at the affordability of sampling, and in the erosion boundary the rock samples are taken in more detail.

Furthermore, the data processing and analysis stage is carried out, where at this stage rock samples are prepared so that samples of fossil sieve are produced. Equipment needed in the preparation of this sample include $\mathrm{H}_{2} \mathrm{O}_{2}$ solution, filter / mesh (mesh 16, mesh 32, mesh 42, mesh 80), methyl blue, scales, and oven. The sample was weighed to get a sample weighing $100 \mathrm{gr}$, then the weighed sample is cleaned using $\mathrm{H}_{2} \mathrm{O}_{2}$ solution so that it is clean from mud. Furthermore, it is done again using ultrasonic washing so that the granules are completely clean of mud. Then sieving using a filter / mesh on flowing water is obtained so that the microfossil samples of various sizes are obtained. The fossil sample is then inserted into the oven so that it is dry and ready to be observed. In the sample preparation, it is then applied to apply methyl blue to the filter to avoid mixing fossils. The next step is to identify fossils using a binocular microscope, where the identification of fossil planktonic foraminifera refers to Postuma (1971), Bolli \& Saunders (1985), and Li et al. (2003), while identification of benthic foraminifera refers to Jones (1994). From the identification of fossils the data obtained are recorded in the fossil list table and distribution chart.

Based on the measured stratigraphy results, an analysis is carried out to produce the lithofacies unit of the research area. While based on the results of fossil identification, biostratigraphy and paleobathimetry analysis were carried out. Determination of biostratigraphic zones refers to Blow (1969) and Wade et al. (2011). Then, an analysis of the sedimentation rates and identification of unconformity was carried out by integrating biostratigraphic data, paleobatimetry and absolute age of the biodatum. The absolute age of the biodatum will refer to Wade et al. (2011). 


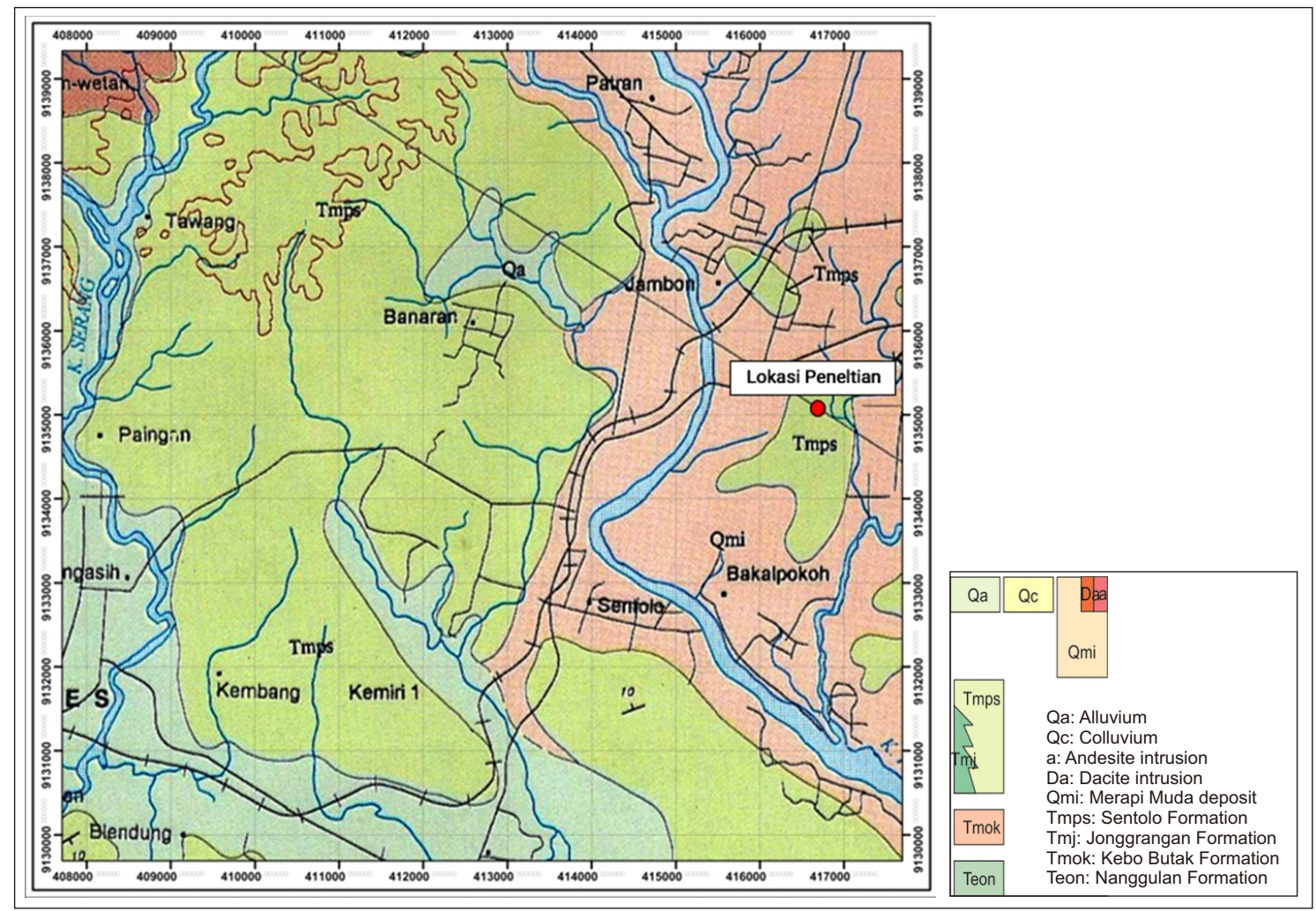

Figure 1: Geological map of Yogyakarta (Rahardjo et al., 1995) and research location.

\section{RESUlTS AND Discussion}

\subsection{Lithofacies}

Based on observations in the field, the research area can be divided into three facies, that is:

\section{A. Thickening upward calcareous sandstone - cal- careous siltstone facies}

This facies develops at the bottom of the outcrop in the study area, has a thickness of about $12 \mathrm{~m}$ (intervals $0-12 \mathrm{~m}$ ). This facies consists of interbedded calcareous sandstone and calcareous siltstone, which has a white to gray color and thickening upward pattern. The sedimentary structure that develops in this facies is only bedding structure and normal graded bedding (Figure $2 \& 3$ ).

\section{B. Channel calcareous sandstone - calcareous silt- stone facies}

This facies develops in the middle of the outcrop in the study area, has a thickness of about $7.1 \mathrm{~m}$ (interval 12-19.1 m). This facies consists of calcareous sandstone intercalated with calcareous siltstone that has medium sand to coarse sand size. Unlike the previous facies, calcareous sandstones in this facies have massive and channels structures which have a thick- ness that is quite thick and thinning towards the edge. In addition, this facies also found sedimentary structures in the form of trace fossil iomorpha. At the top of this facies, a flute cast sediment structure was found and then an erosional boundary was identified at the upper limit of this unit.

\section{Thinning upward limestone facies}

This facies develops at the top of the outcrop in the study area, has a thickness of about $3.1 \mathrm{~m}$ (interval 19.1-22.2 m). The lower limit of this facies is restricted by the erosional boundary. This facies consists of white to brown grainstone and packstone with thinning upward pattern. The sedimentary structure that develops in this facies is bedding and normal graded bedding.

\subsection{Biostratigraphy zonation}

Observation of planktonic foraminifera fossils in the Sedayu area was carried out on 11 rock samples. From the total sample, 37 species of planktonic foraminifera were identified, where the distribution and abundance of species can be seen in the Table 1, then the plate fossil can be seen in Appendices. In general, based on bios- 

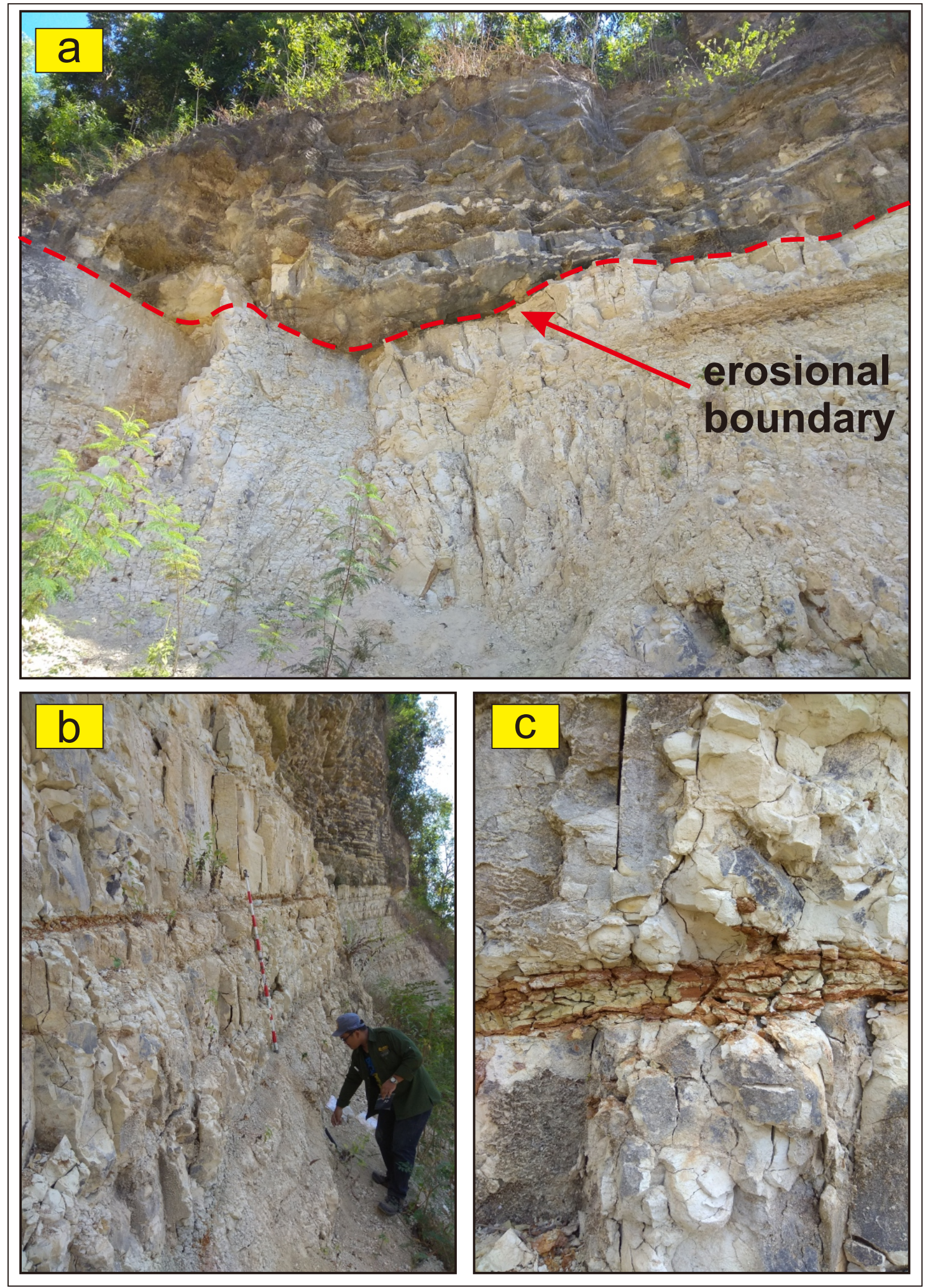

Figure 2: (a) Erosional boundary on base of thinning upward facies, (b) appearance of thickening upward calcareous sandstone - calcareous siltstone facies, and (c) appearance of channel calcareous sandstone - calcareous siltstone facies. 


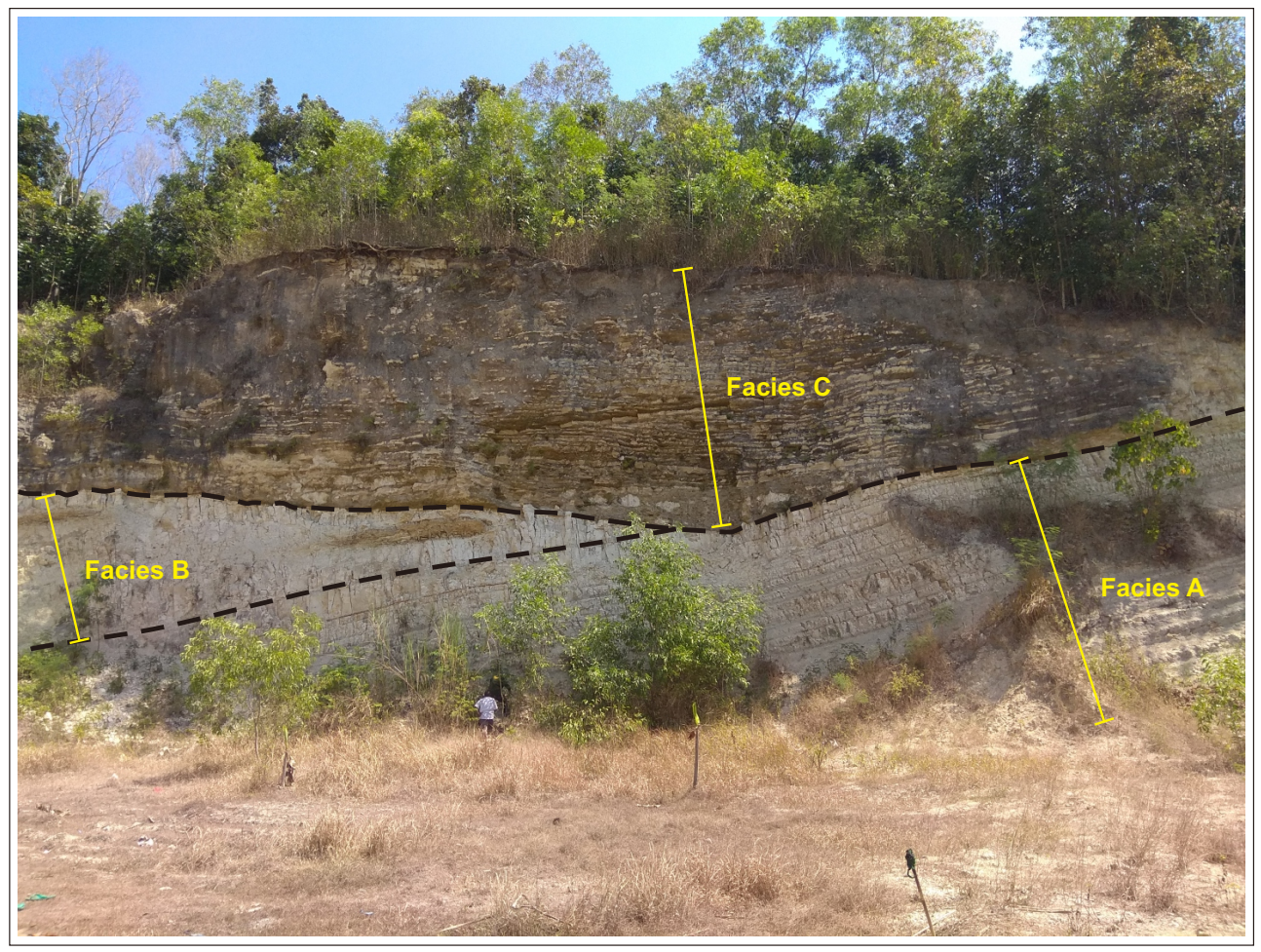

Figure 3: Outcrops of calcareous sandstone, calcareous siltstone, and limestone in the Sedayu area. There are three facies, that are Facies A (thickening upward calcareous sandstone - calcareous siltstone), Facies B (channel calcareous sandstone - calcareous siltstone), and Facies C (thinning upward limestone).

tratigraphic analysis in the Sedayu area can be divided into 4 zones (Figure 4), there is:

\section{A. Globorotalia tumida tumida zone (PL1A)}

The Globorotalia tumida tumida zone is a partial range zone that is equivalent to the PL1 zone (Wade et al., 2011) and the N18 zone (Blow, 1969). The datum at the bottom of this zone is not found, while the top of this zone is restricted by the first occurrence (FO) of Sphaerodinella dehischens in the SDY005 sample. The naming of this zone was based on the index fossil content that most characterized the age of this zone, that is Globorotalia tumida tumida. The thickness of this zone if limited to the bottom of the data collection is $3.8 \mathrm{~m}$.

B. Sphaerodinella dehischens-Sphaerodinellopsis kochi zone (PL1B)

Sphaerodinella dehischens-Sphaerodinellopsis kochi zone is a concurrent range zone that is equivalent to the middle of PL1 zone (Wade et al., 2011) and N18 zones (Blow, 1969). The bottom of this zone is restricted by the first occurrence (FO) of Sphaerodinella dehischens in the SDY005 sample, while the top of this zone is restricted by the last occurrence (LO) of Sphaerodinellopsis kochi in the SDY012 sample. The naming of this zone is based on fossil index which limit top and bottom of this zone. The thickness of this zone is $14.4 \mathrm{~m}$.

\section{Globorotalia menardii A zone (PL1C)}

The Globorotalia menardii A zone is the concurrent range zone that is equivalent to the upper part of PL 1 zone (Wade et al., 2011) and the upper part of N18 zone (Blow, 1969). The bottom of this zone is restricted by the last occurrence (LO) of Sphaerodinellopsis kochi in the SDY012 sample, while the top of this zone is restricted by three biodatums, namely the last occurrence (LO) of Globorotalia menardii A, first occurrence (FO) of Globorotalia crassaformis and first occurrence (FO) Globorotalia exilis in the SDY014 sample. The discovery of more than one biodatum with different ages in the same sample indicates an unconformity that restricted the upper part of this zone. The naming of this zone is based on a fossil index that limits the top of this zone, that is Globorotalia menardii A. The thickness of this zone is $0.9 \mathrm{~m}$. 
AKMALUDDin et al.

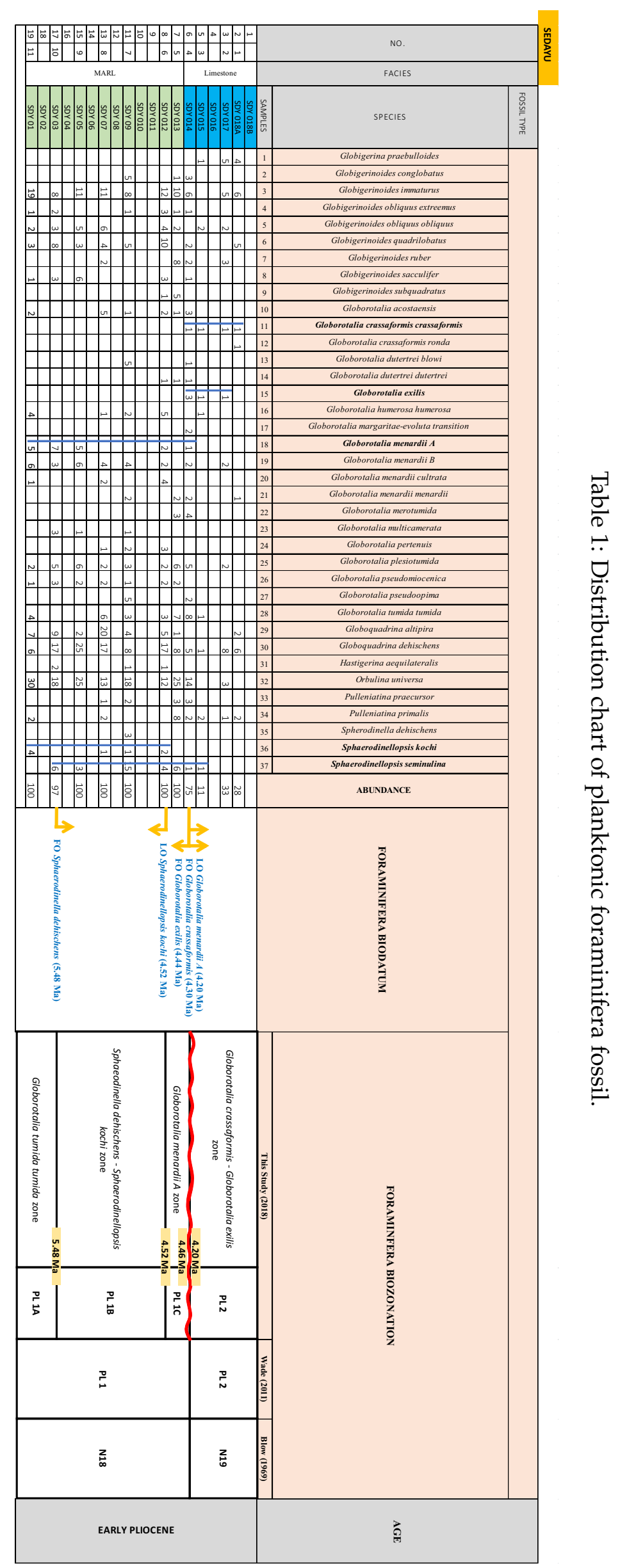




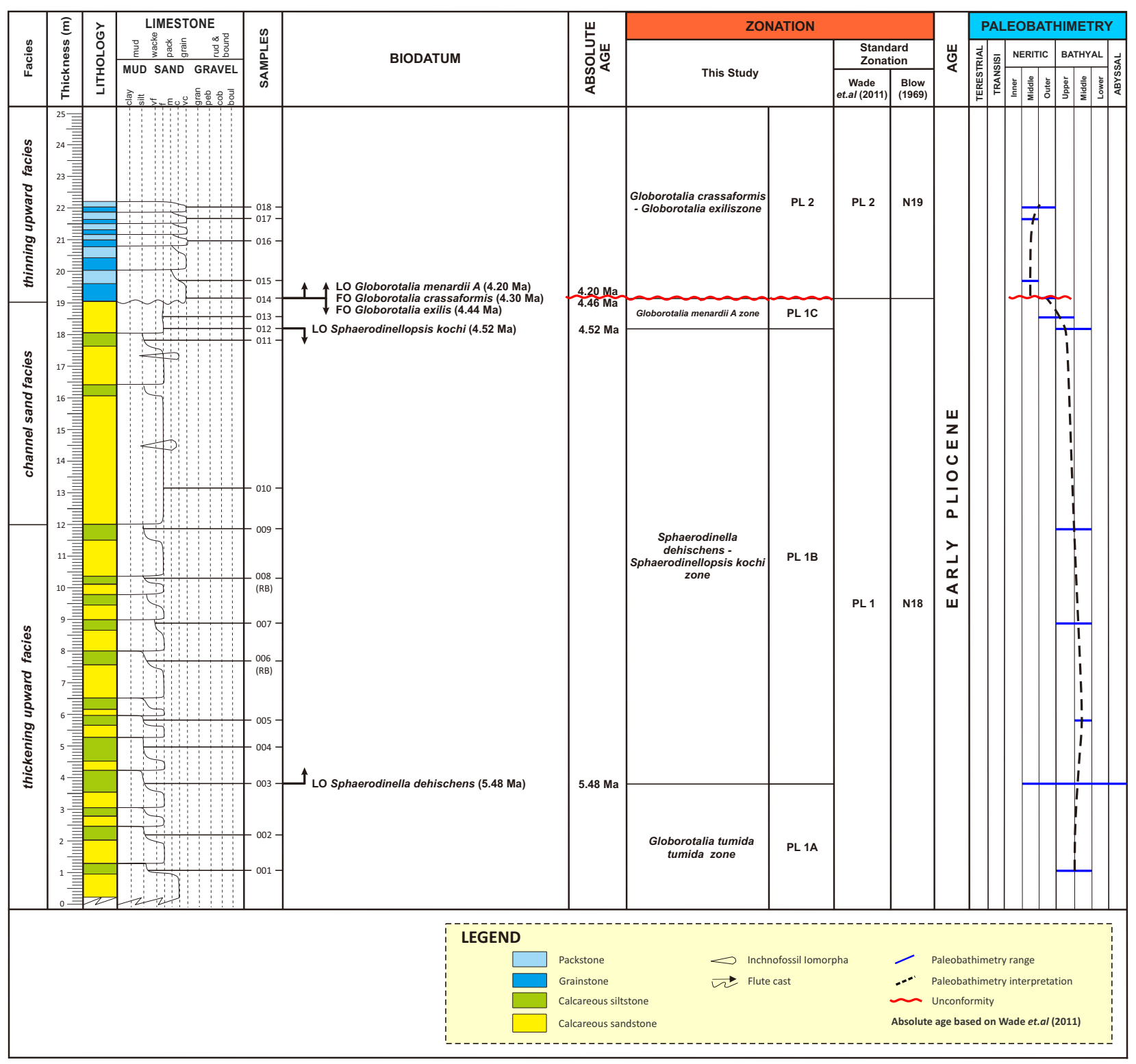

Figure 4: Stratigraphic column, biostratigraphy zones and paleobathimetry of Sedayu area. 
D. Globorotalia crassaformis-Globorotalia exilis zone (PL2)

Globorotalia crassaformis-Globorotalia exilis zone is a partial range zone equivalent to the PL2 zone (Wade et al., 2011) and N19 zone (Blow, 1969). The bottom of this zone is restricted by first occurrence (FO) of Globorotalia crassaformis and first occurrence (FO) Globorotalia exilis in the SDY 014 sample, whereas at the top of this zone no biodatum is found. The naming of this zone is based on the content of the fossil index which limits the bottom of this zone, namely Globorotalia crassaformis and Globorotalia exilis. The thickness of this zone if limited to the top of the data collection is $3.2 \mathrm{~m}$.

\subsection{Paleobathimetry}

Determination of paleobathimetry is based on the content of existing benthic foraminifera. From the total sample, 25 species of foraminifera benthics were identified, where the distribution and abundance of the species can be seen in the Table 2, the the plate fossil can be seen in Appendices.

In general, the results of the analysis of paleobathimetry (Figure 4) show that at the bottom (SDY001-SDY011 sample) is formed in Upper Bathyal to Middle Bathyal paleobathimetry. Then began to show shallowing in the SDY012 sample into the Upper Bathyal environment. In the SDY013-SDY014 sample, it was identified a paleobathimetric gap which the environment suddenly changed from initially on Upper Bathyal to Middle Neritic in short intervals. This indicates an unconformity at that interval. Finally, at the top (SDY015-SDY018) the environment tends to remain Middle Neritik with a slight deepening at the top.

\subsection{Biochronology}

When referring to Wade et al. (2011), the biodatum used in this study is known for its absolute age (??). From the absolute age data, the sedimentation rates in the study area can be calculated. In addition, it can also be used to identify age of unconformity. The absolute age values of the biodatum used in this study are as follows.

\subsection{Sedimentation rates and unconformity identification}

Based on the sedimentation rates analysis in the Sedayu area (Figure 5), one pattern of sed- imentation rates was identified. The pattern has a sedimentation rates value of $15.5 \mathrm{~m} / \mathrm{Ma}$ that takes place during the formation of thickening upward calcareous sandstone-calcareous siltstone facies and channel calcareous sandstone-calcareous siltstone facies. Furthermore, above the unconformity, the value of the sedimentation rates cannot be identified because there is no more than one biodatum.

Then, based on the results of biostratigraphy and paleobathimetry analysis, identification of the presence of unconformity can be done. In addition, the absolute age of the biodatum which is the boundary of each zonation can be used to calculate the sedimentation rates by dividing the thickness of the sediment by that age difference. Before calculating sedimentation rates, it is necessary to identify unconformity because generally it will affect the sedimentation rates.

In the study area, there were indications of unconformity, that is at the boundary between the channel calcareous sandstone-calcareous siltstone facies with the thinning upward limestone facies (samples SDY013 and SDY014). The unconformity was identified from the presence of three biodatums with relatively different ages in the same sample, as well as indications of a paleobathimetric gap in the SDY013-SDY014 sample. Using the sedimentation rates below it $(15.5 \mathrm{~m} / \mathrm{Ma})$, extrapolation was carried out and it was known that the age of bottom of the unconformity is at 4.46 Ma. Whereas the age of top of this unconformity cannot be calculated using extrapolation because there is no data on sedimentation rates above the unconformity, so that the age of top unconformity is considered the same as the youngest biodatum which restricted this unconformity, which is LO Globorotalia menardii A with age 4.20 Ma.

When calculating using the sedimentation rates below it $(15.5 \mathrm{~m} / \mathrm{Ma})$, the eroded thickness during unconformity $(4.46-4.20 \mathrm{Ma})$ is around 4.03 meters (Figure 5). Based on the duration of unconformity and eroded thickness which tends to be thin, it is suspected that this unconformity is not a regional unconformity, but only local unconformity. 


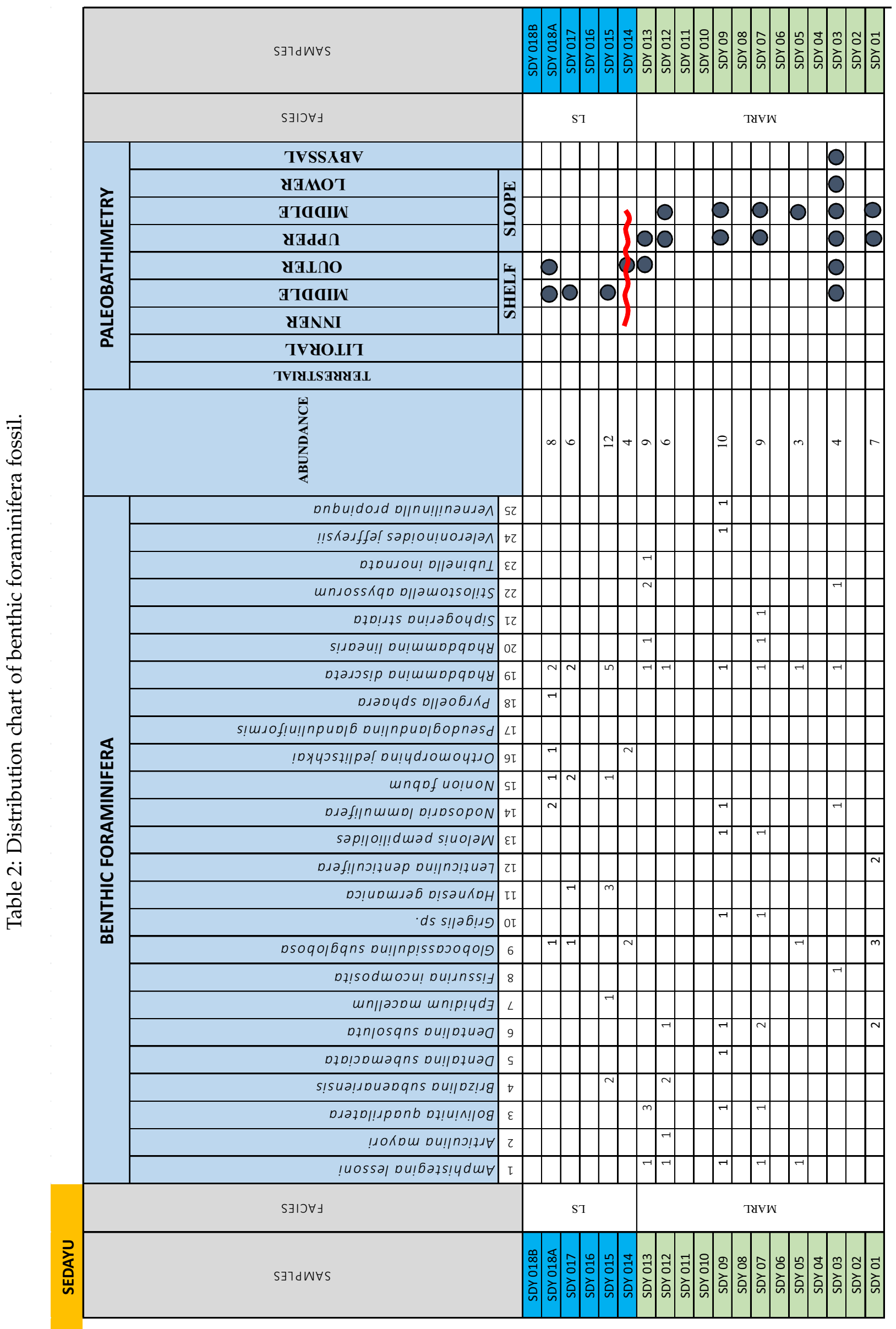




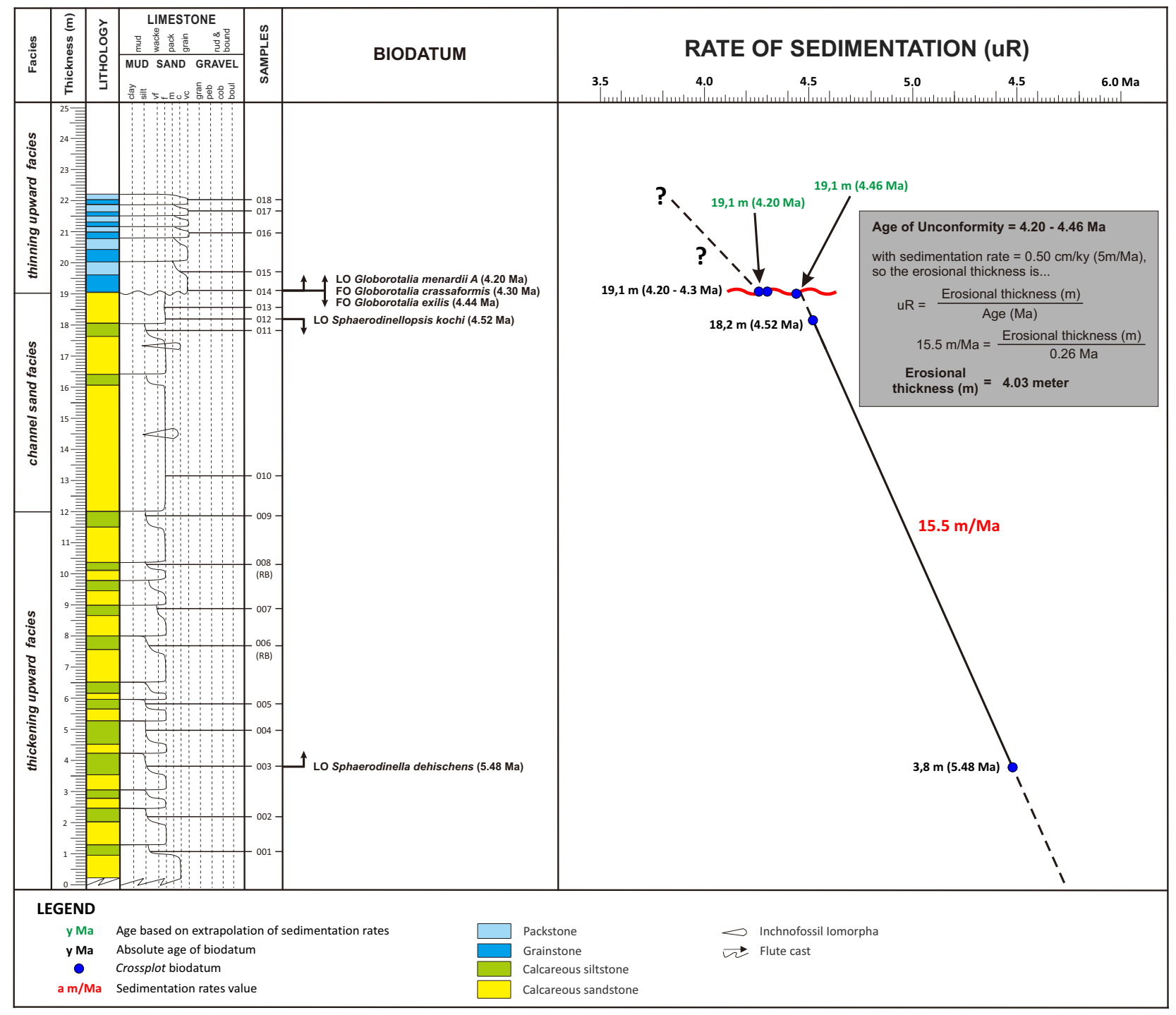

Figure 5: Identification of sedimentation rates and unconformities age. 
Table 3: Absolute age of biodatum in the study area.

\begin{tabular}{|c|c|c|}
\hline No. & Biodatum & $\begin{array}{c}\text { Absolute } \\
\text { Age (Wade } \\
\text { et al., 2011) }\end{array}$ \\
\hline 1 & $\begin{array}{c}\text { FO Sphaerodinella } \\
\text { dehischens }\end{array}$ & $5.48 \mathrm{Ma}$ \\
\hline 2 & $\begin{array}{c}\text { LO Sphaerodinellopsis } \\
\text { kochi }\end{array}$ & $4.52 \mathrm{Ma}$ \\
\hline 3 & FO Globorotalia exilis & $4.44 \mathrm{Ma}$ \\
\hline 4 & $\begin{array}{c}\text { FO Globorotalia } \\
\text { crassaformis }\end{array}$ & $4.30 \mathrm{Ma}$ \\
\hline 5 & $\begin{array}{c}\text { LO Globorotalia } \\
\text { menardii } A\end{array}$ & $4.20 \mathrm{Ma}$ \\
\hline
\end{tabular}

\section{CONCLUSION}

The Sentolo Formation in the Serayu area is composed of three lithofacies, that is thickening upward calcareous sandstone-calcareous siltstone facies, channel calcareous sandstone-calcareous siltstone facies and thinning upward limestone facies. These facies are formed at the age of the Early Pliocene, where biostratigraphy can be divided into four biostratigraphic zones, namely Globorotalia tumida tumida zone (PL1A), Sphaerodinella dehischens-Sphaerodinellopsis kochi zone (PL1B), Globorotalia menardii A (PL1C), and Globorotalia crassaformis-Globorotalia exilis zone (PL2).

The unconformity in the boundary of the channel calcareous sandstone-calcareous silstone facies with the thinning upward limestone facies was identified. On the appearance in the field, the unconformity was identified from the presence of an erosion boundary between the boundaries of the two facies, whereas based on paleobathimetry it also supported this with the sudden change in paleobathimetry from Upper Batial to Middle Neritic. The sedimentation rates identified in this area has a value of $15.5 \mathrm{~m} / \mathrm{Ma}$ during the formation of thickening upward calcareous sandstone-calcareous siltstone facies and channel calcareous sandstone-calcareous siltstone facies, while at the top it cannot be calculated because no biodatum are found. The extrapolation results of age and sedimentation rates concluded that the unconformity occurred at the age of $4.46-4.20 \mathrm{Ma}$, and caused a $4.03 \mathrm{~m}$ thick sedimentary rock to eroded.

\section{ACKNOWLEDGEMENTS}

This study was supported by research grant from Department of Geological Engineering UGM. The authors wish to express thanks to field geological teams in Sedayu area (Dr. Didit Hadi Barianto and Berli Sahala Simorangkir, S.T.)

\section{REFERENCES}

Armstrong, H., \& Brasier, M. (2005) Microfossils, Blackwell Publishing, United Kingdom.

Berggren, W.A., Kent, D.V., Swisher, C.C., Aubry, M. (1995) A revised Cenozoic geochronology and chronostratigraphy. In: Berggren, W.A., Kent, D.V., Aubry, M.-P., Hardenbol, J. (Eds.), Geochronology Time Scales and Global Stratigraphic CorrelationSEMP Special Publication, vol. 54, pp. 129-212.

Blow, W.H. (1969) Late Middle Eocene to Recent Planktonik Foraminiferal Biostratigraphy. In Bronnimann P. and Renz, H.H. (eds.) $1^{\text {st }}$ Conference on Planktonik Microfossils Proceedings (Geneva, 1967). E.J. Brill, Leiden, v. 1, h. 199-412, 43 gbr., 54 pl.

Bolli, H., M., Saunder, J. B., dan Nielsen, Pearch K. (1985) Plankton Stratigraphy. Cambridge University Press.

Jones, R.W. (1994) Challenger Foraminifera. Oxford: Oxford University Press, 149 pp.

Komisi Sandi Stratigrafi Indonesia (1996) Sandi Stratigrafi Indonesia, Ikatan Ahli Geologi Indonesia, Jakarta.

Leckie, R. Mark, Farnham, C., Schmidt, M.G. (1993) Oligocene Planktonic Foraminifer Biostratigraphy of Hole 803D (Ontong Java Plateu) and Hole 628A (Little Bahama Bank), and Comparison with the Southerns High Latitudes, In Berger, W.H., Wise, S.W., Jr., Schlich, R., et al., Proc. ODP, ScII. Results, 130 (Pt. 2): College Station, TX (Ocean Drilling Program), 113-130.

Rahardjo, W., Sukandarrumidi, dan Rosidi, H.M.D. (1995) Peta Geologi Lembar Yogyakarta, Jawa, Edisi ke-2, Pusat Penelitian dan Pengembangan Geologi, Bandung.

Van Bemmelen, R.W. (1949) The Geology of Indonesia, Vol. I.A. General Geology. Martinus Nyhoff, The Hague.

Wade, B. S., Pearson, P. N., and Berggren, W. (2011) Review and Revision of Cenozoic Tropical Planktonic Foraminiferal Biostratigraphy and Calibration to the Geomagnetic Polarity and Astronomical Time Scale, Earth Science Riview 104. 
AKMALUDDIN et al.

A Plate of Planktonic and Benthic FORAMINIFERA FOSSILS 


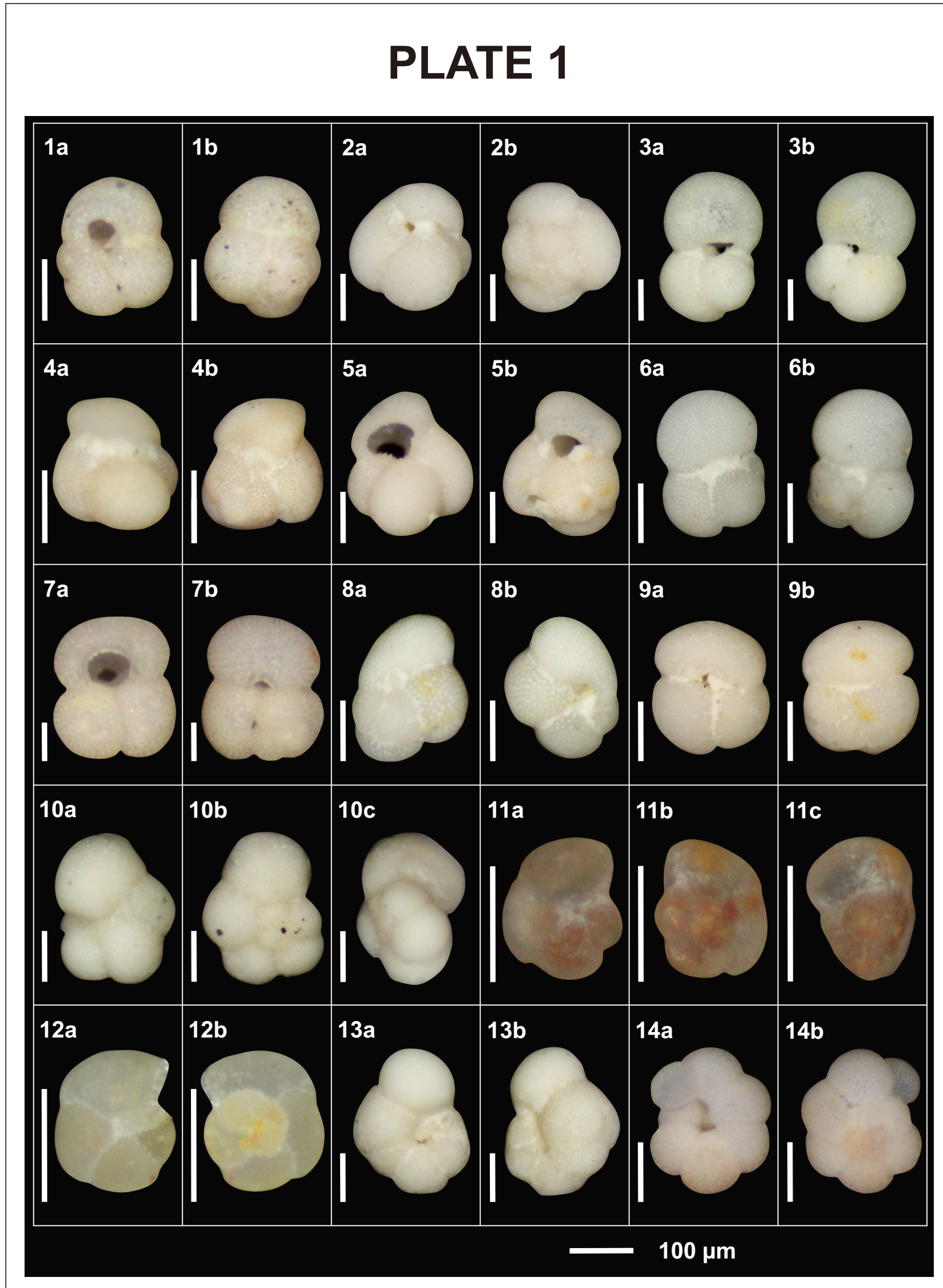

1. Globigerina praebulloides

2. Globigerinoides conglobatus

3. Globigerinoides immaturus

4. Globigerinoides obliquus extreemus

5. Globigerinoides obliquus obliquus

6. Globigerinoides quadrilobatus

7. Globigerinoides ruber
8. Globigerinoides sacculifer

9. Globigerinoides subquadratus

10. Globorotalia acostaensis

11. Globorotalia crassaformis crassaformis

12. Globorotalia crassaformis ronda

13. Globorotalia dutertrei blowi

14. Globorotalia dutertrei dutertrei 


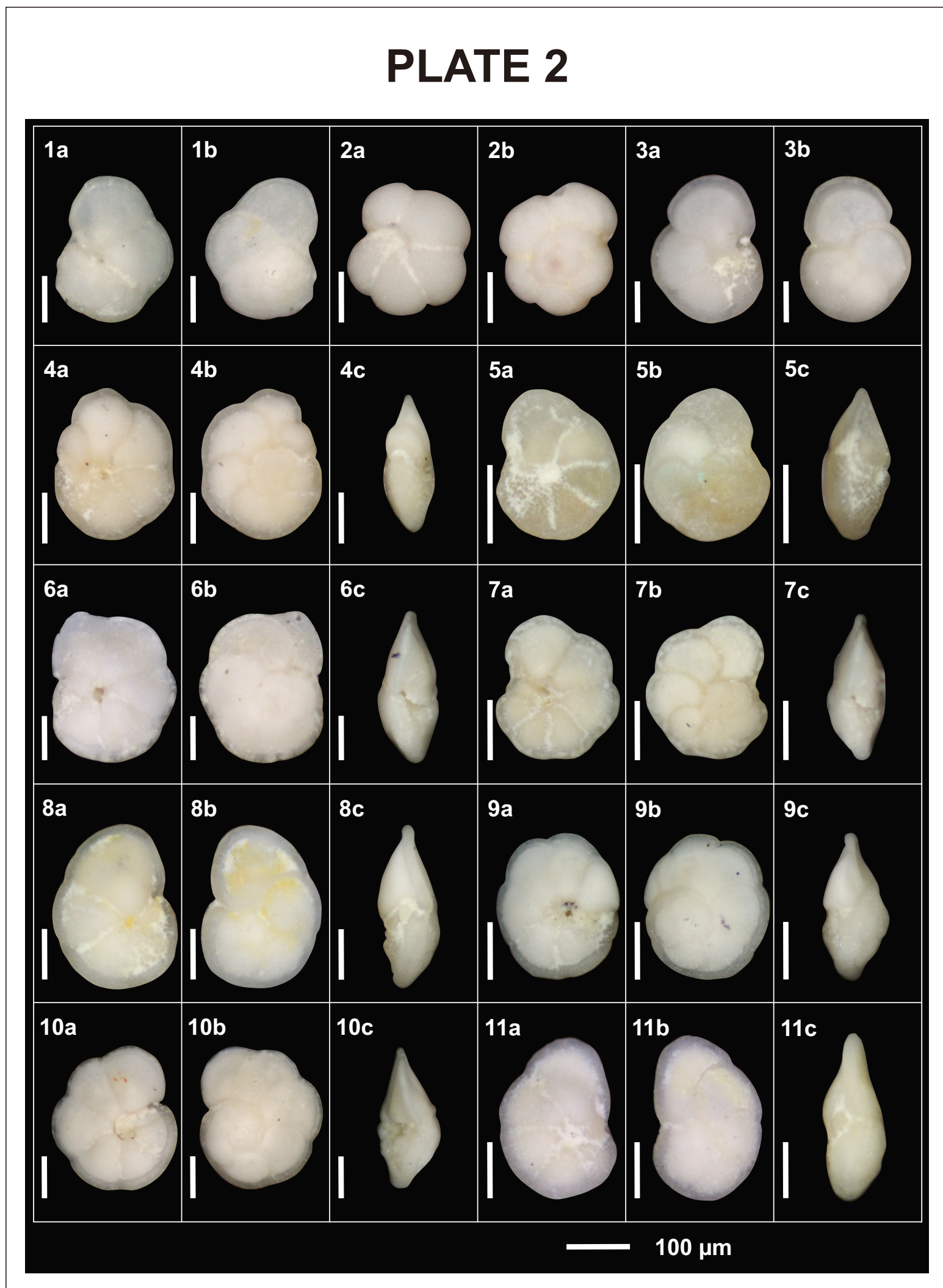

1. Globorotalia exilis

2. Globorotalia humerosa humerosa

3. Globorotalia margaritae-evoluta transition

4. Globorotalia menardii A

5. Globorotaliamenardii $B$
6. Globorotalia menardii cultrata

7. Globorotaliamenardii menardii

8. Globorotalia merotumida

9. Globorotalia multicamerata

10. Globorotaliapertenuis

11. Globorotaliaplesiotumidai 


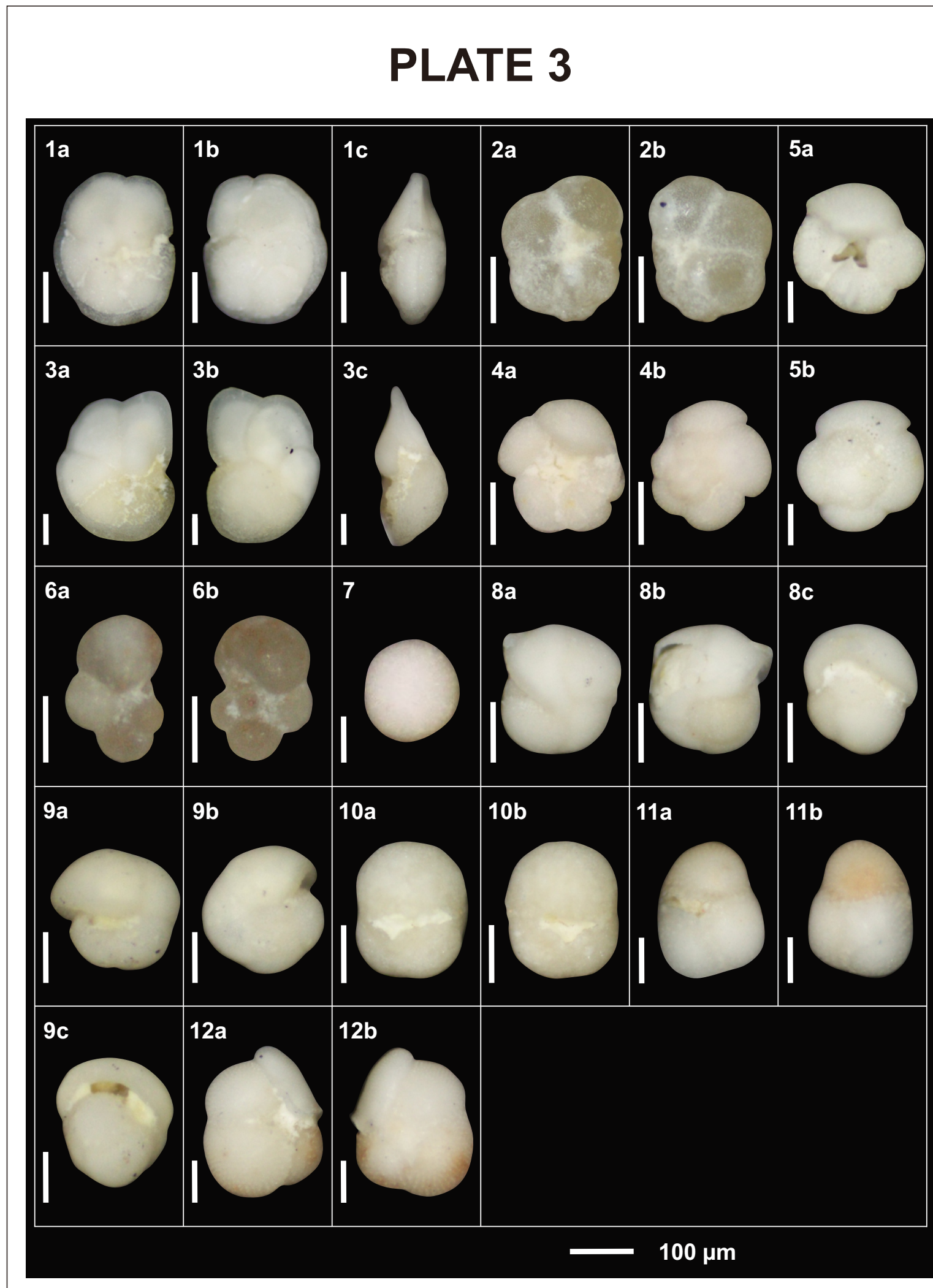

1. Globorotaliapseudomiocenica

2. Globorotaliapseudoopima

3. Globorotalia tumida tumida

4. Globoquadrina altipira

5. Globoquadrina dehischens

6. Hastigerina aequilateralis
7. Orbulina universa

8. Pulleniatina praecursor

9. Pulleniatina primalis

10. Spherodinella dehischens

11. Sphaerodinellopsis kochi

12. Sphaerodinellopsis seminulina 


\section{PLATE 4}

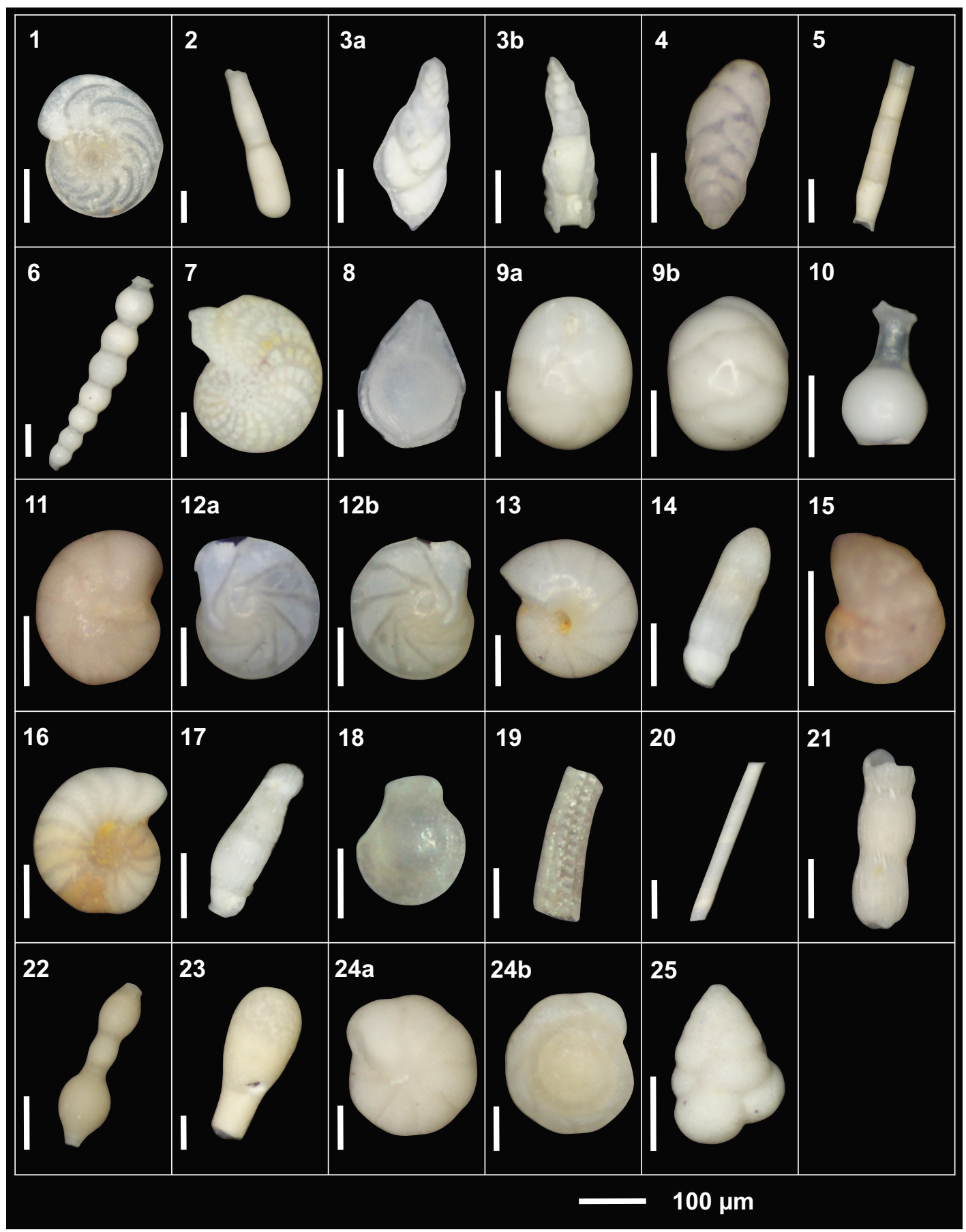

1. Amphistegina lessoni

2. Articulina mayori

3. Bolivinita quadrilatera

4. Brizalina subaenariensis

5. Dentalina subemaciata

6. Dentalina subsoluta

7. Ephidium macellum

8. Fissurina incomposita

9. Globocassidulina subglobosa
10. Grigelis sp.

11. Haynesia germanica

12. Lenticulina denticulifera

13. Melonis pempiliolides

14. Nodosaria lammulifera

15. Nonion fabum

16. Orthomorphina jedlitschkai

17. Pseudoglandulina glanduliniformis

18. Pyrgoella sphaera
19. Rhabdammina discreta

20. Rhabdammina linearis

21. Siphogerina striata

22. Stilostomella abyssorum

23. Tubinella inornata

24. Veleroninoides jeffreysii

25. Verneuilinulla propinqua 